\title{
Purification, structural analysis, and stability of antioxidant peptides from purple wheat bran
}

\author{
Yan Zhao ${ }^{1,2^{*}}$, Qi Zhao ${ }^{1,2}$ and Qingyu Lu ${ }^{1,2}$
}

\begin{abstract}
Protein derived from purple wheat bran was hydrolyzed sequentially using alcalase proteases for the production of antioxidant peptides. Purple wheat bran protein (PWBP) hydrolysates were fractionated using size-exclusion (G-25) and ion-exchange chromatography methods to identify the structure of antioxidant peptides. The free radical scavenging activity of peptides purified from PWBP hydrolysates was evaluated using superoxide anion radical-scavenging activity and determination assays of Trolox equivalent antioxidant capacity (TEAC). Results demonstrated that purple wheat bran peptide F4-4 exhibited the highest antioxidant activity among other hydrolysates. F4-4 was further identified as Cys-Gly-Phe-Pro-Gly-His-Cys, Gln-Ala-Cys, Arg-Asn-Phe, Ser-Ser-Cys, and Trp-Phe by high performance liquid chromatography (HPLC) spectrometer coupled with Orbitrap Elite ${ }^{\mathrm{TM}}$ mass spectrometer (LC-MS/MS). Antioxidant peptides 2 and 4 showed improved stability when the temperature was lower than $80^{\circ} \mathrm{C}$. These peptides also demonstrated good digestive stability in vitro system by simulating gastrointestinal digestion.
\end{abstract}

Keyword: Purple wheat bran, Antioxidant peptide, Purification, Structural analysis, Stability

\section{Introduction}

Antioxidants are substances that counteract the oxidation reaction caused by free radicals. Antioxidants are used to extend the shelf life of foods because they reduce lipid oxidation [1]. Synthetic antioxidants are commonly used in the food industry [2]. The most widely used synthetic antioxidants are butylated hydroxy anisole (BHA), butylated hydroxytoluene (BHT), and tert-butylhydroquinone (TBHQ). However, the use of synthetic antioxidants is strictly regulated because of their adverse effects to human health [3]. Studies have shown that these synthetic antioxidants can have varying degrees of toxicity in humans and affect the liver, spleen, and lung [4-6]. Therefore, the use of these synthetic chemical substances has been strictly limited [7]. Currently, considerable attention has been provided to natural antioxidants due

\footnotetext{
*Correspondence: zhaoyanss10@126.com

${ }^{1}$ National Engineering Laboratory of Wheat \& Corn Further Processing,

Henan University of Technology, Zhengzhou 450001, China

Full list of author information is available at the end of the article
}

to their high efficacy and little or no side effects compared with synthetic antioxidants $[8,9]$.

Peptides derived from natural sources are natural antioxidants. These antioxidants have been the focus of research interest because of their potential health benefits associated with low molecular weight, low cost, high activity, functional properties, and safety [10, 11]. Many studies have produced bioactive peptides from plant protein sources. Thus, natural antioxidants from grains, vegetables, and plant substrates are crucial in protecting the body from reactive oxygen species (ROS) damage. Bioactive peptides can act as inhibitors of lipid peroxidation to scavenge free radicals directly [11] and prevent damages associated with oxidative stress in humans with regular consumption [9]. Most antioxidant peptides are small in size (less than $1 \mathrm{kDa}$, typically bioactive peptides), have 2 to 20 amino acid residues per chain, and usually contain a high proportion of hydrophobic amino acids [9]. Previous studies have shown that antioxidative peptides can be purified from several plant protein hydrolysates, such as soybean [12], rapeseed [11], wheat[13], and rice bran [14]. Several antioxidant properties of these peptides,

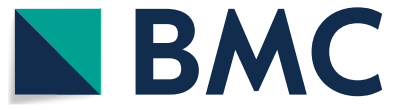

(c) The Author(s) 2020. This article is licensed under a Creative Commons Attribution 4.0 International License, which permits use, sharing, adaptation, distribution and reproduction in any medium or format, as long as you give appropriate credit to the original author(s) and the source, provide a link to the Creative Commons licence, and indicate if changes were made. The images or other third party material in this article are included in the article's Creative Commons licence, unless indicated otherwise in a credit line to the material. If material is not included in the article's Creative Commons licence and your intended use is not permitted by statutory regulation or exceeds the permitted use, you will need to obtain permission directly from the copyright holder. To view a copy of this licence, visit http://creativeco mmons.org/licenses/by/4.0/. The Creative Commons Public Domain Dedication waiver (http://creativecommons.org/publicdomain/ zero/1.0/) applies to the data made available in this article, unless otherwise stated in a credit line to the data. 
including their capability to inactivate ROS, scavenge free radicals, and chelate pro-oxidative transition metals $[15$, 16], have been described.

Purple wheat is one of the wheat varieties. Most studies on purple wheat bran investigated its anthocyanins because of its color [11, 17]. However, these studies ignored the importance of purple wheat bran as a protein resource and its capability to extract antioxidant peptides. In the present study, the hydrolysis of purple wheat bran by a protease to produce peptides with high antioxidant activities was studied. Furthermore, the antioxidant peptides were isolated and purified, sequenced, and studied for stability.

\section{Materials and methods Materials}

Purple wheat (Triticum aestivum L.) of the cultivar Shannong Purple Wheat One were harvested in August, 2018 (base on the GB 1351-2008) at maturity from Shangdong, China. Purple wheat bran protein (PWBP) was prepared from purple wheat bran. Alcalase $(2 \times 105 \mathrm{U} / \mathrm{g})$, flavourzyme $(3 \times 104 \mathrm{U} / \mathrm{g})$, papain $(8 \times 105 \mathrm{U} / \mathrm{g})$, neutral enzyme $(3 \times 104 \mathrm{U} / \mathrm{g})$, and trypsin $(2.5 \times 105 \mathrm{U} / \mathrm{g})$ were purchased from Beijing Solarbio Science \&Technology Co., Ltd. (Beijing, China) DETA-Sepharose FF and Sephadex G-25 were purchased from Beijing Solarbio Science \&Technology Co., Ltd. (Beijing, China).

\section{Enzymatic hydrolysis of PWBP}

Pretreated PWBP (2 g) was dissolved in $100 \mathrm{~mL}$ of distilled water and then hydrolyzed with alcalase $\left(50{ }^{\circ} \mathrm{C}\right.$, $\mathrm{pH} 8.0)$, flavourzyme $\left(53^{\circ} \mathrm{C}, \mathrm{pH} 6.4\right)$, papain $\left(50{ }^{\circ} \mathrm{C}, \mathrm{pH}\right.$ 7.0), neutral enzyme $\left(39^{\circ} \mathrm{C}, \mathrm{pH} 7.0\right)$, and trypsin $\left(45^{\circ} \mathrm{C}\right.$, $\mathrm{pH}$ 8.0) respectively under their optimal conditions as recommended by the manufacturer. These five enzymes have a hydrolysis time of $60 \mathrm{~min}$ and an enzyme addition of $14,000 \mathrm{U} / \mathrm{g}$, and then heated in $100{ }^{\circ} \mathrm{C}$ water bath for $10 \mathrm{~min}$ to inactivate the enzymes. Degree of hydrolysis (DH), peptide yield and the TEAC of PWBP hydrolysates were determined. The best enzyme was selected and hydrolyzed for $0.5-3 \mathrm{~h}$. DH, peptide yield and TEAC were determined every $0.5 \mathrm{~h}$. The $\mathrm{DH}$ and peptide yield were determined by $\mathrm{pH}$-stat method and Lowry method $[18,19]$. TEAC was determined as described in 2.4.2.

\section{Purification of antioxidant peptides from PWBP hydrolysates Sephadexed-G25 chromatography}

PWBP hydrolysates, which were prepared by alcalase as chosen in 2.2, applied onto a Sephadexed-G25 column $(1.5 \times 75 \mathrm{~cm})$ and eluted with deionized water at a flow rate of $1.6 \mathrm{~mL} / \mathrm{min}$ and monitored at $280 \mathrm{~nm}$. The active fractions were collected, lyophilized and determined their antioxidant activities using the methods described in 2.4. The best strong antioxidant fraction was selected and used as material in next chromatography separation step.

\section{lon exchange chromatography}

The fraction exhibiting antioxidant activity by 2.3.1 was loaded onto a DEAE-Sepharose Fast Flow column $(1.6 \times 30 \mathrm{~cm})$, which was earlier equilibrated with $20 \mathrm{mM}$ Tris- $\mathrm{HCl}$ buffer $(\mathrm{pH} 8.0)$ and eluted with a linear gradient of $\mathrm{NaCl}(0-1.0 \mathrm{~mol} / \mathrm{mL})$ in the same buffer at a flow rate of $0.6 \mathrm{~mL} / \mathrm{min}$. Each fraction separated and purified by ion exchange chromatography was monitored at $280 \mathrm{~nm}$, collected at a volume of $3 \mathrm{~mL}$ and concentrated using a vacuum rotary evaporator. Antioxidant activities of separated fractions were investigated using the methods described in 2.4.

\section{Determination of antioxidant activities Superoxide anion radical scavenging activity assay}

Superoxide anion radical scavenging activity assay was measured using the pyrogallol autoxidation method with some modifications [20]. Mix $1.6 \mathrm{~mL}$ of sample with an equal volume of $50 \mathrm{mM}$ Tris- $\mathrm{HCl}$ buffer ( $\mathrm{pH}$ 8.3). The mixture was incubated in a bath for $20 \mathrm{~min}$, then $0.8 \mathrm{~mL}$ of $1.5 \mathrm{mM}$ pyrogallic acid was added. Absorbance of the mixture was measured at $320 \mathrm{~nm}$ every $30 \mathrm{~s}$ for $5 \mathrm{~min}$. For blank, $1.6 \mathrm{~mL}$ of Tris-HCl buffer was used instead of sample. Ascorbic acid and GSH were used as positive controls. Superoxide anion radical scavenging activity was calculated as: $\mathrm{O} 2-$ clearancerate $(\%)=\frac{1-\Delta \mathrm{OD}_{\mathrm{S}}}{\Delta \mathrm{OD}_{\mathrm{b}}} \times 100 \%$,

Where, $\Delta \mathrm{OD}_{\mathrm{S}}$ and $\Delta \mathrm{OD}_{\mathrm{b}}$ represented slope of absorbance line for sample and slope of absorbance line for blank.

\section{Determination of Trolox equivalent (TE) antioxidant capacity (TEAC)}

The experiment referred to methods of Costa and Xing and made appropriate modifications [21, 22]. This method used Trolox as the standard antioxidant and all reagents were prepared in $50 \mathrm{mmol} / \mathrm{L}$ phosphate buffered solution ( $\mathrm{pH}$ 7.4). The specific operation was as follows: PBS $(50 \mu \mathrm{L})$ solution (blank group), different concentrations of Trolox solution (standard control group) and sample solution to be tested (sample group) were added to a transparent 96-well microplate, and then $150 \mu \mathrm{L}$ $\mathrm{ABTS}^{+}$. was quickly added. The solution was shaken at $30{ }^{\circ} \mathrm{C}$ for $30 \mathrm{~min}$ and its absorbance was measured at $734 \mathrm{~nm}$ using a microplate scanning spectrophotometer (Multiskan FC, Thermo Fisher Scientific (Shanghai), China). ABTS radical scavenging activity was calculated as 
Table 1 The DH of PWBP enzymatic hydrolysis by five enzymes, and peptide yield and TEAC of PWBP hydrolysates

\begin{tabular}{lrrrrr}
\hline & \multicolumn{1}{c}{ Alcalase } & Flavourzyme & Papain & \multicolumn{1}{c}{ Netural enzyme } & Trypsin \\
\hline DH (\%) & $4.88 \pm 1.27^{\mathrm{b}}$ & $6.42 \pm 0.25^{\mathrm{a}}$ & $3.05 \pm 0.36^{\mathrm{c}}$ & $3.45 \pm 0.53^{\mathrm{bc}}$ & $3.51 \pm 0.51^{\mathrm{bc}}$ \\
Peptide yield (\%) & $43.67 \pm 8.86^{\mathrm{a}}$ & $9.44 \pm 1.35^{\mathrm{c}}$ & $20.06 \pm 1.84^{\mathrm{b}}$ & $27.74 \pm 0.51^{\mathrm{b}}$ & $23.61 \pm 2.23^{\mathrm{b}}$ \\
TEAC ( $\mu$ mol TE/g) & $917.11 \pm 5.89^{\mathrm{a}}$ & $428.02 \pm 44.00^{\mathrm{b}}$ & $344.34 \pm 6.21^{\mathrm{bc}}$ & $206.33 \pm 5.33^{\mathrm{c}}$ & $783.43 \pm 3.71^{\mathrm{b}}$ \\
\hline
\end{tabular}

Data expressed as means $\pm \mathrm{SD}(n=3)$. Values in the same row followed by different letters were significantly different at $P<0.05$

$$
\mathrm{ABTS}+\cdot \text { clearancerate }(\%)=\left(1-\frac{\mathrm{A}_{\text {Sample }}}{\mathrm{A}_{\mathrm{Blank}}}\right) \times 100
$$

where, $A_{\text {Sample }}$ and $A_{\text {Blank }}$ referred to the absorbance of sample group and blank group, respectively.

\section{Identification of the antioxidative peptides by LC-MS/MS}

For identification of sequences, the purified peptides by 2.3 were subjected to a capillary high performance liquid chromatography (HPLC) spectrometer coupled with Orbitrap Elite ${ }^{\mathrm{TM}}$ mass spectrometer source at Biotech-Pack Scientific Co., Ltd. (Beijing, China). Following molecular mass determination, the peptide was automatically selected for fragmentation, and sequence information was obtained by tandem mass spectroscopy (MS/MS) analysis. Data were processed using Xcalibur software (Thermo Scientific MS software) and the Maxquant (1.6.2.10) auxiliary tool within the protein database restricted to wheat entries.

\section{Synthesis of antioxidant peptides}

The identified purple wheat bran antioxidant peptides were synthesized by the solid phase method using 9-fluorenylmethoxycarbonyl (FMOC) amino acids method at Biotech-Pack Scientific Co., Ltd. (Beijing, China). The purity of the synthesized peptides was greater than $90 \%$.

\section{Stability study}

\section{Temperature stability}

The antioxidant activities of purple wheat bran antioxidant peptides at different passivation temperatures for $60 \mathrm{~min}$ were studied. The detection method of antioxidant activities was shown in 2.4. Before the antioxidant activities were measured, the samples allowed to cool to room temperature $\left(25^{\circ} \mathrm{C}\right)$ and $\mathrm{pH}$ was adjusted to 7.0.

\section{In vitro digestion stability}

According to the main components of human gastrointestinal digestive juice and digestive environment, a human gastrointestinal digestion simulation system was established to study the antioxidant activity changes of peptides after digestion by human gastrointestinal digestion simulation system. The method was according to the previously reported by Jang et al. [23].

\section{Statistical analyses}

All experiments were carried out in triplicate, and all results were expressed as the mean \pm standard deviation. Results were analyzed by one-way analysis of variance with SPSS (Version 20, IBM Corp., Armonk, NY). Means followed by different letters were significantly different according to Duncan's multiple range test at $P<0.05$ level.

\section{Results and discussion}

\section{Enzymatic hydrolysis of PWBP by various proteases}

The degree of hydrolysis (DH) of purple wheat bran protein (PWBP), which was enzymatically hydrolyzed by alcalase, flavourzyme, papain, neutral enzyme, and trypsin, as well as the peptide yield and Trolox equivalent antioxidant capacity (TEAC) of PWBP hydrolysates, were investigated in this study (Table 1). Results showed that the peptide yield and the TEAC of PWBP hydrolysates prepared from alcalase were remarkably higher than those of the other enzymes' hydrolysates. The DH of PWBP hydrolysates by flavourzyme was substantially higher than those of other enzymes, their peptide yield and TEAC were lower than those of alcalase. Therefore, alcalase was selected to prepare the hydrolysates of PWBP.

Moreover, the DH of PWBP and the peptide yield of PWBP hydrolysates prepared by alcalase increased in $0.5-2 \mathrm{~h}$ and remained stable for the remaining $2-3 \mathrm{~h}$ (Fig. 1). This result was consistent with that of the general proteolytic curve studied by Pedro Valencia et al. [24]. The TEAC of PWBP hydrolysates by alcalase increased in $0.5-2 \mathrm{~h}$ and gradually decreased with the increase in time (Fig. 1). The TEAC results might be due to the cleavage of most peptide bonds during hydrolysis [25]. The antioxidant activity of wheat bran peptide decreased when the $\mathrm{DH}$ of the substrate exceeded the optimal DH of the wheat bran peptide. DH, peptide yield, and TEAC were the highest at 9.88\%, $45.70 \%$, and $1331.10 \mu \mathrm{mol} \mathrm{TE} / \mathrm{g}$, respectively, when the PWBP hydrolysates were prepared by alcalase for $2 \mathrm{~h}$. 


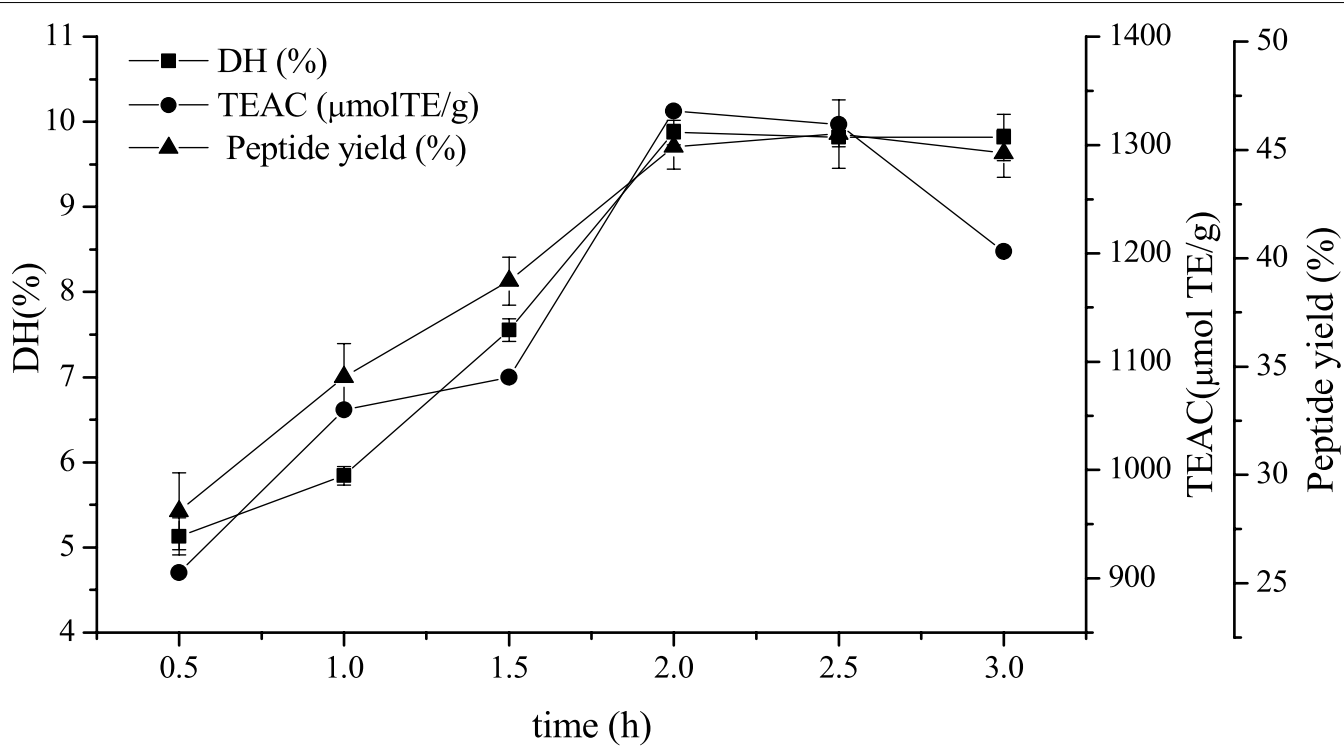

Fig. 1. Changes in DH of PWBP enzymatic hydrolysis by Alcalase, and peptide yield and TEAC of PWBP hydrolysates in different times. Data expressed as means $\pm S D(n=3)$

Therefore, hydrolysis time with alcalase in the subsequent experiments was $2 \mathrm{~h}$.

\section{Purification of antioxidant peptides from PWBP hydrolysates}

Purple wheat bran protein hydrolysates were initially separated by size-exclusion chromatography through a Sephadex G-25. The profiles of PWBP hydrolysates and the antioxidant activity of each component are shown in Fig. 2. Purple wheat bran protein hydrolysates were fractionated into four fractions (F1-F4). Results show that fraction 4 (F4) possesses the highest antioxidant capacity. Figure $2 \mathrm{~b}$ reveals that the superoxide anion radical scavenging activity and TEAC of F4 were $43.72 \% \pm 2.9 \%$ and $4760 \pm 1.1 \mu \mathrm{mol} \mathrm{TE} / \mathrm{g}$, respectively (Fig. $2 \mathrm{~b}$ ).

F4 was further subjected to ion-exchange chromatography on a DEAE-Sepharose Fast Flow column and separated into F4-1, F4-2, F4-3, and F4-4 (Fig. 3a). The F4-4 exhibited superoxide anion radical scavenging activity and TEAC of $70.27 \%$ and $3600 \mu \mathrm{mol} \mathrm{TE} / \mathrm{g}$, respectively, which were remarkably higher than those of the other fractions (Fig. 3b). Therefore, the F4-4 fraction was collected for determining amino acid sequences.

\section{Sequence identification}

The peptide sequence is of considerable importance in determining the antioxidant activity of active peptides $[16,26]$. Thus, identifying the specific features of the sequences of antioxidant peptides are necessary. The mass spectrum is shown in Fig. 4a, and the tandem mass spectra of peptide 1-peptide 5 are shown in Fig. $4 \mathrm{~b}-\mathrm{f}$.
The matching result provided the following putative amino acid sequences: Cys-Gly-Phe-Pro-Gly-His-Cys, Gln-Ala-Cys, Arg-Asn-Phe, Ser-Ser-Cys, and Trp-Phe.

Kim et al. and Qian et al. [27, 28] studied the majority of antioxidant peptides and showed that those with low molecular weight are efficient antioxidants. Moreover, they found that bioactive peptides usually contain less than 20 amino acid residues per molecule and can cross the intestinal barrier and exert biological effects. In the present study, all five antioxidant peptides had low molecular weights $(<600 \mathrm{Da})$, which are consistent with the results of Kim et al. and Qian et al. Therefore, the five peptides identified in this experiment had improved antioxidant activity.

Almost all bioactive peptides containing Tyr, Leu, Ala, Ile, Val, Lys, Phe, Cys, Met, and His exhibit high antioxidant activities [9]. Another study also indicated that antioxidative peptides often contain hydrophobic amino acid residues, such as Pro, Tyr, Trp, Met, Gln, and Ala, which are generally considered antioxidants in some cases $[1,29,30]$. The present results show the following: peptide 1 (Fig. 4b) contains Cys, Phe, Pro, and His; peptide 2 (Fig. 4c) contains Gln, Ala, and Cys; peptide 3 (Fig. 4d) contains Phe; peptide 4 (Fig. 4e) contains Cys; and peptide 5 (Fig. 4f) contains Trp and Phe. Therefore, the antioxidant activity of peptides 1 to 5 isolated from purple wheat bran is also related to the existence of the aforementioned amino acids. This finding is consistent with that of Kou et al. [16].

Qian [28] found that His, Trp, and Phe with aromatic residues can stabilize ROS through direct electron 

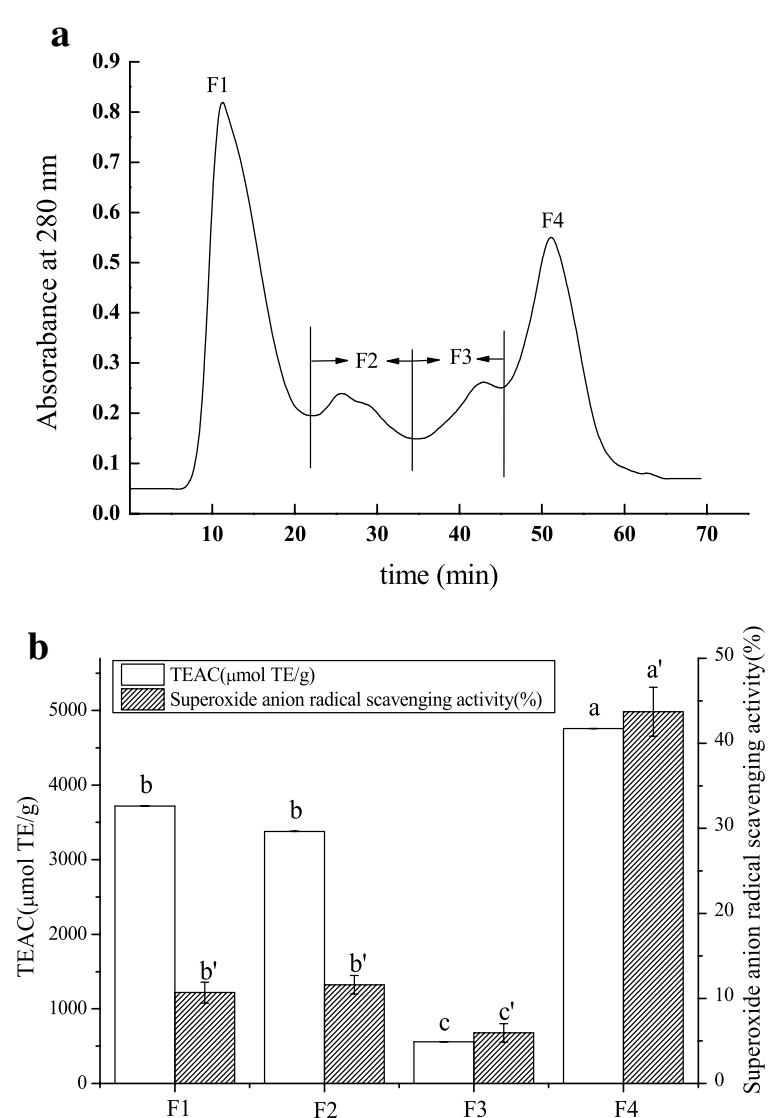

Fig. 2. The profiles of PWBP hydrolysates using size exclusion chromatogram on a Sephadex G-25 column (a) and superoxide anion radical scavenging activity and TEAC of various fractions at peptide concentration of $5 \mathrm{mg} / \mathrm{mL}$. Means $(n=3)$ followed by the same letter were not significantly different according to Duncan's multiple range test at $\mathrm{P}<0.05$ level

transfer. Moreover, Phe, which positively acts as a direct radical scavenger [31], was also present in the antioxidative peptide sequences of peptides 1 (Fig. 4b), 3 (Fig. 4e), and 5 (Fig. 4f) in the present study. Phe could also be partly responsible for the antioxidant activity of these peptides.

Sequence analysis indicated that peptides 1 (Fig. 4b), 2 (Fig. 4c), and 4 (Fig. 4e) contained hydrophobic amino acids, such as Cys. Qian et al. [28] found that Cys is crucial for antioxidant action because it can directly interact with radicals. Thus, the antioxidant activity of peptides 1, 2, and 4 are assumed to be related to Cys. Previous research also confirmed this finding. Harman et al. [32] reported that the thiol group of Cys is crucial in protecting cells and cellular biomolecules from oxidative stress.

Based on these results, peptides with low molecular weight and good antioxidant activities were obtained

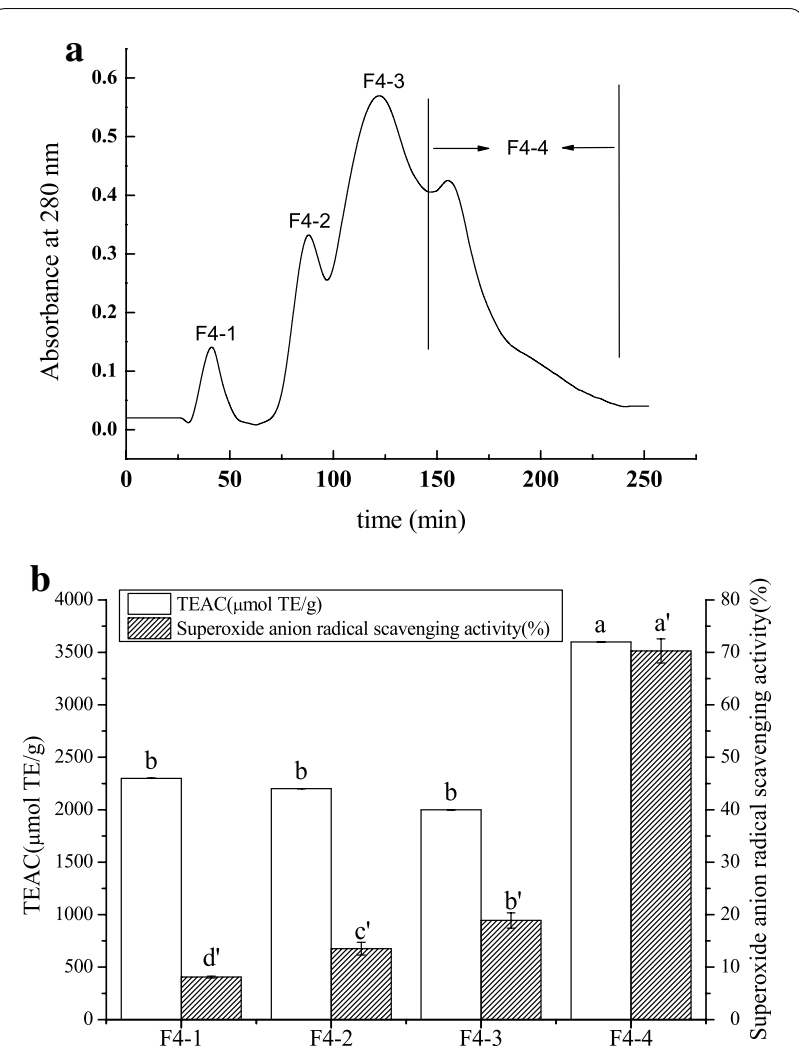

Fig. 3. Ion exchange chromatogram of $\mathrm{F} 4$ on a DEAE-Sepharose Fast Flow column (a) and superoxide radical scavenging activity and TEAC of various fractions at peptide concentration of $5 \mathrm{mg} / \mathrm{mL}$ (b). Means $(n=3)$ followed by the same letter were not significantly different according to Duncan's multiple range test at $\mathrm{P}<0.05$ level

from PWBP by enzymatic hydrolysis to enhance the utilization value of PWBP and avoid resource waste.

Evaluation of antioxidant activities of synthesized peptides Superoxide radical is a deleterious free radical that can cause serious damage to human tissues [33]. Jin [34] found that the measurement of scavenging superoxide radical was based on the principle that antioxidants can scavenge superoxide anion radicals generated in the process of pyrogallol autoxidation and inhibit the autoxidation reaction of pyrogallol. As shown in Fig. 5a, the superoxide anion radical scavenging capability of the five synthesized peptides presented a dose-dependent relationship. The antioxidant capacities of the five peptides were all lower than those of ascorbic acid and glutathione (GSH) at $1.0-3.0 \mathrm{mg} / \mathrm{mL}(P<0.05)$. However, peptides 2 and 4 exhibited higher superoxide anion radical scavenging activities than those of the three other peptides $(P<0.05)$. Furthermore, the IC50 values of peptides 1,2 , 3,4 , and 5 were $2.898,2.473,3.662,2.145$, and $3.271 \mathrm{mg} /$ 


\section{a}

ZQ\#4312-4980 RT: 12.24-13.68 AV: 53 NL: 1.46E6

[30.0000-1400.0000]
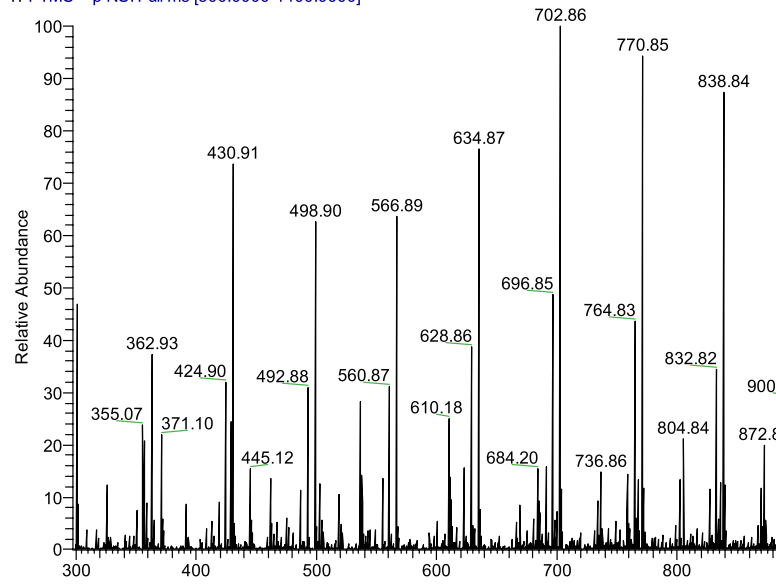


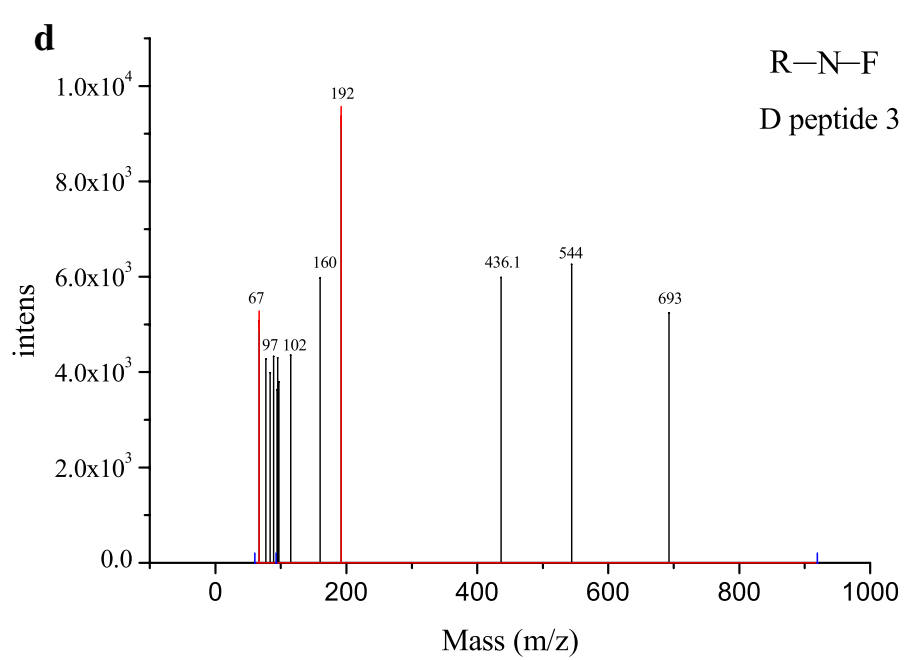

e
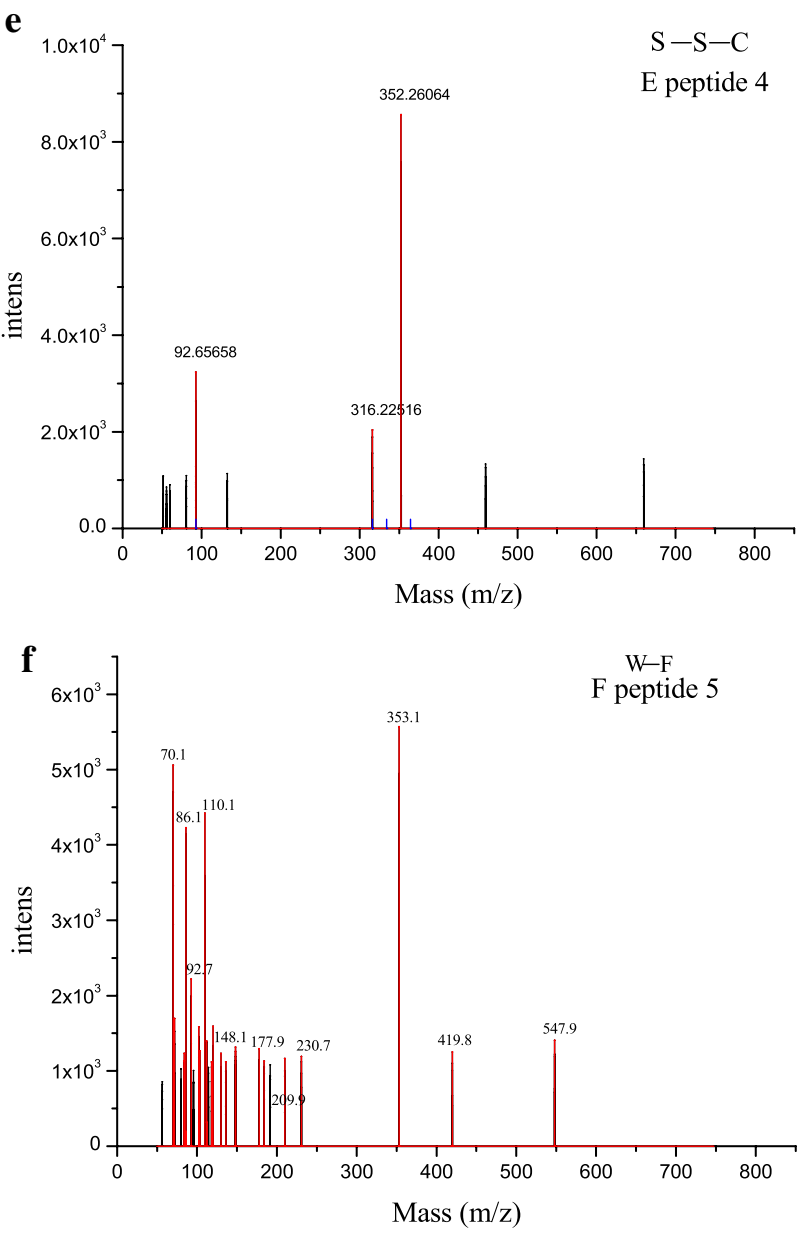

Fig. 4. continued 

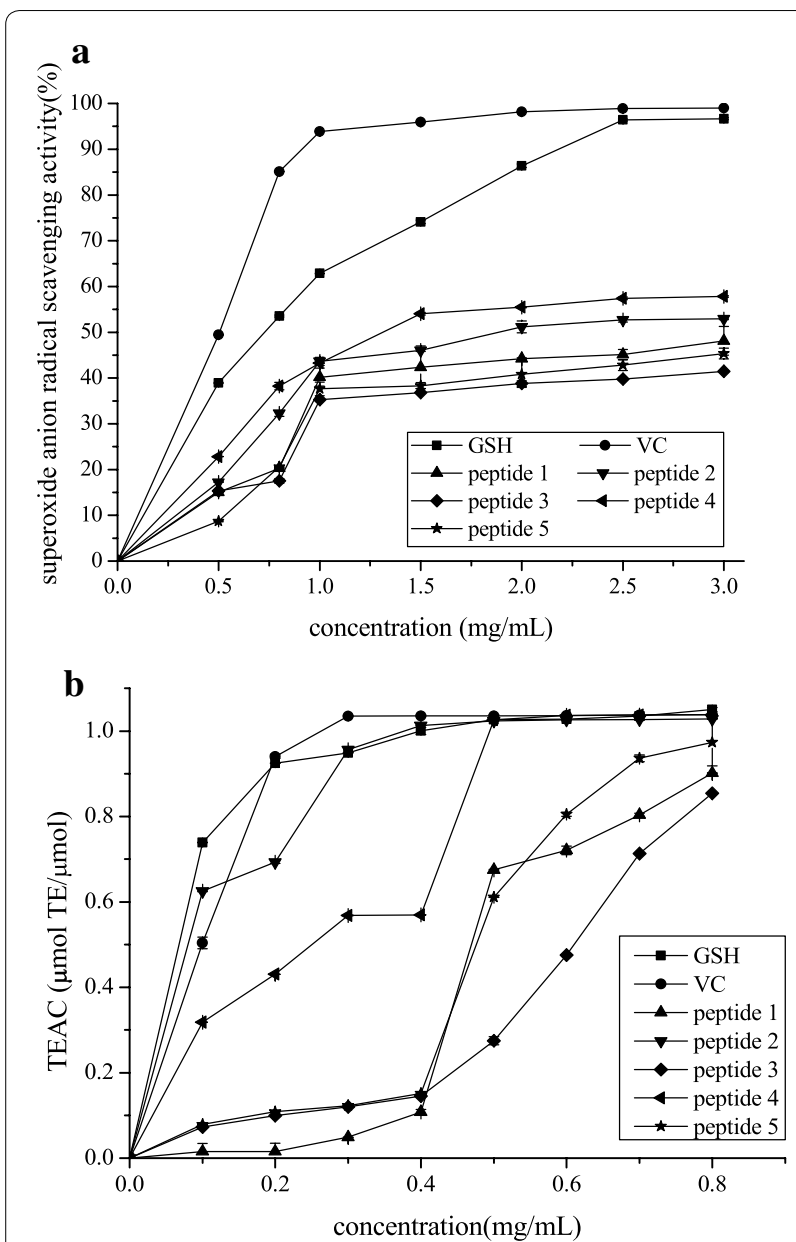

Fig. 5. Effect of antioxidant peptide concentration on superoxide anion radical scavenging activity $(\mathbf{a})$ and TEAC (b) of five synthetic peptides. Data expressed as means $\pm S D(n=3)$

mL, respectively. Thus, peptides 2 and 4 can be considered good superoxide anion radical scavengers.

As shown in Fig. 5b, the TEAC of peptides 2 and 4 were excellent in the concentration range of $0.1-0.8 \mathrm{mg} / \mathrm{mL}$, which were significantly higher than those of the three other peptides $(P<0.05)$. In addition, the TEAC of peptide 2 at $1-0.4 \mathrm{mg} / \mathrm{mL}$ was better than that of peptide 4 at $0.5-0.8 \mathrm{mg} / \mathrm{mL}$, and the TEAC of peptides 2 and 4 were substantially the same as those of ascorbic acid and GSH $(P<0.05)$. However, no significant differences were observed among the TEAC of peptide 2 and peptide 4 $(P>0.05)$. The IC50 values of peptides $1,2,3,4$, and 5 were $0.763,0.092,0.877,0.205$, and $0.750 \mathrm{mg} / \mathrm{mL}$, respectively. Thus, peptides 2 and 4 exhibited better antioxidant capacities than that of the three other peptides.

Peptides 2 and 4 synthesized in this study might be better antioxidants than the other peptides because of their high resistance to superoxide anion radical and high TEACs (Fig. 5) $(P<0.05)$. The peptide concentrations for

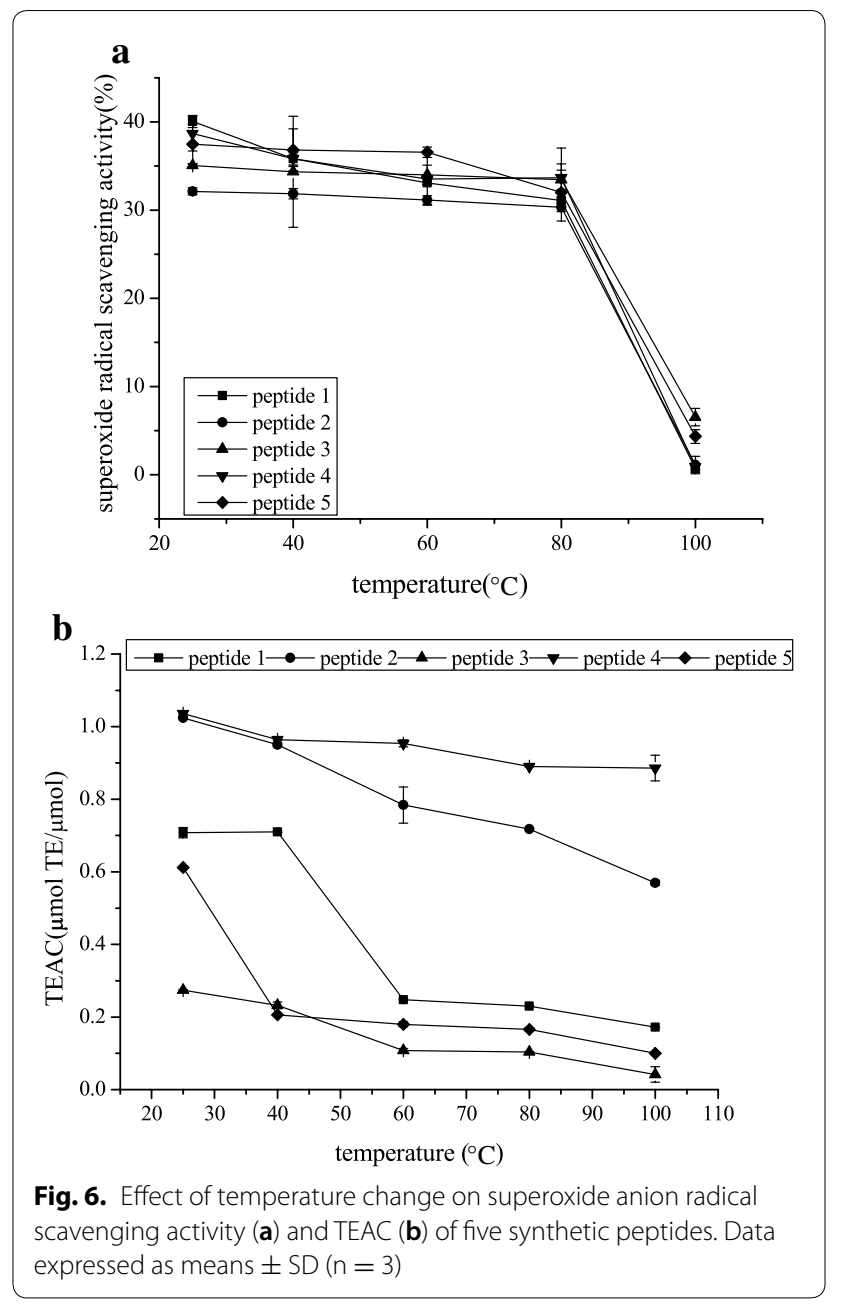

the determination of superoxide anion radical scavenging activity and TEAC in the stability study (3.5 and 3.6) were chosen to be 1.0 and $0.5 \mathrm{mg} / \mathrm{mL}$, respectively, according to the experimental results.

\section{Temperature stability}

The superoxide anion scavenging capability of each peptide slightly decreased in varying degrees as the temperature increased from $25{ }^{\circ} \mathrm{C}$ to $80{ }^{\circ} \mathrm{C}(P>0.05)$ but sharply declined when the temperature was raised to $80{ }^{\circ} \mathrm{C}-100{ }^{\circ} \mathrm{C}(P<0.05)$. In addition, no significant differences were found among the superoxide anion radical scavenging activity of the five peptides $(P>0.05)$.

As shown in Fig. $6 \mathrm{~b}$, the TEAC of the five peptides all increased in varying degrees and those of peptides 2,4 , and 5 significantly increased $(P<0.05)$ as the temperature rose from $25{ }^{\circ} \mathrm{C}$ to $40{ }^{\circ} \mathrm{C}$. However, the TEAC of the five peptides demonstrated downward trends at $60{ }^{\circ} \mathrm{C}-100{ }^{\circ} \mathrm{C}$. The TEAC of peptides 2 and 4 were significantly higher than those of the three other peptides 

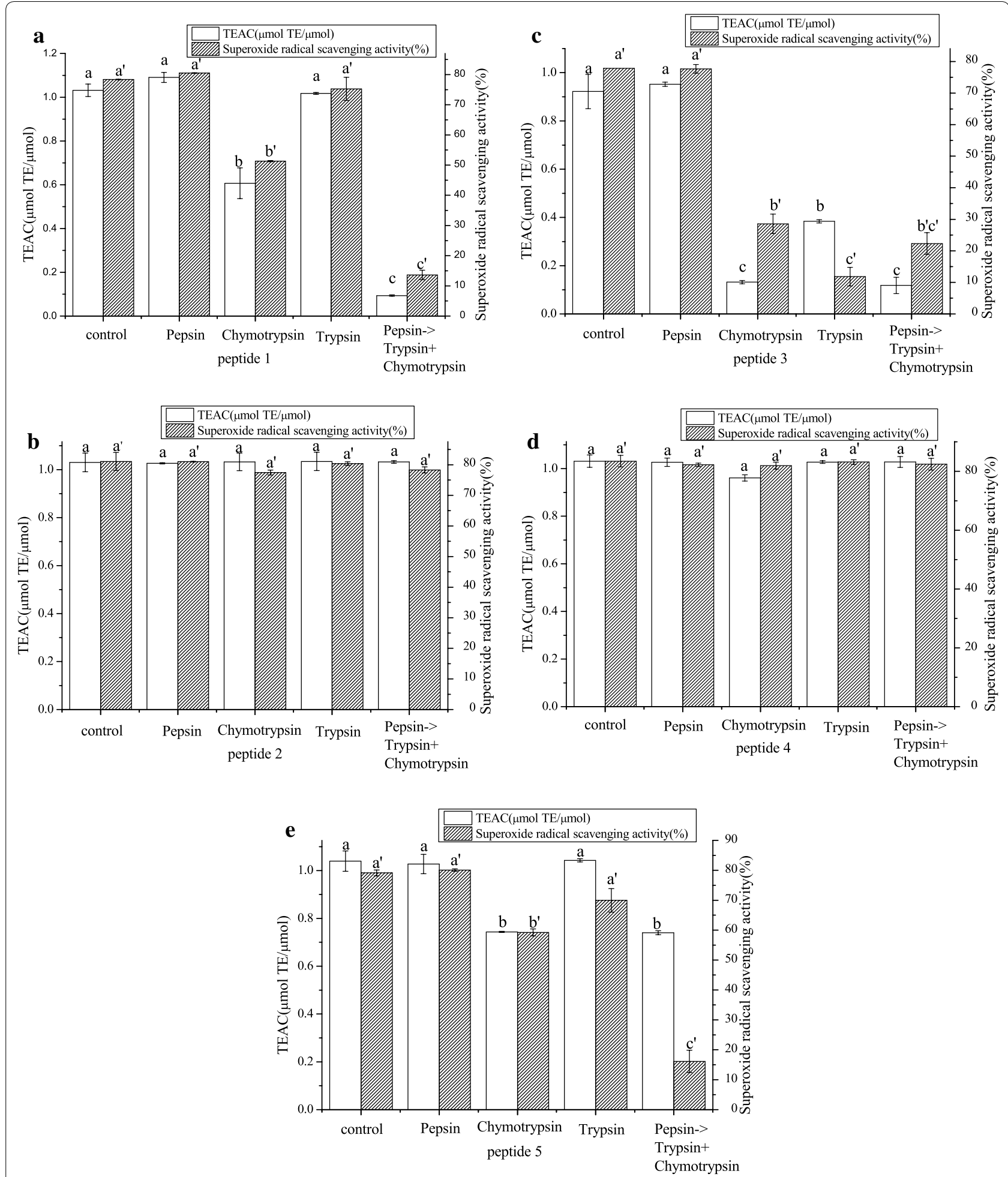

Fig. 7. Effects of in vitro digestion on TEAC and superoxide anion radical scavenging activity of five peptide $(\mathbf{a}, \mathbf{b}, \mathbf{c}, \mathbf{d}, \mathbf{e})$. Data expressed as means $\pm S D(n=3)$.Means followed by the same letter were not significantly different according to Duncan's multiple range test at $P<0.05$ level 
at $25{ }^{\circ} \mathrm{C}-100{ }^{\circ} \mathrm{C}$, and the TEAC of peptide 4 was significantly higher than that of peptide $2(P<0.05)$ at $60{ }^{\circ} \mathrm{C}-100{ }^{\circ} \mathrm{C}$. The TEAC trends of the five peptides were consistent with the antioxidant activities of peptides from sardines studied by Jiang et al. [23]. Moreover, these trends were in agreement with data from previous studies, demonstrating that most proteins were denatured at temperatures from $60{ }^{\circ} \mathrm{C}$ to $100{ }^{\circ} \mathrm{C}$ [35]. These trends may be due to the absence of tertiary and quaternary structures in short-chain and low molecular weight peptides (only those proteins with molecular weight $\geq 50 \mathrm{kDa}$ can form quaternary structures). However, these peptides can still form secondary structures, which are the key factors affecting antioxidant activities. Temperatures higher than $60{ }^{\circ} \mathrm{C}$ will affect the secondary structure, thus leading to unstable antioxidant activities [36].

Based on these results, peptides 2 and 4 exhibited better temperature stability compared with that of the three other peptides. Thus, peptides 2 and 4 might have good thermal processing stability.

\section{In vitro digestion stability}

Figure $7 \mathrm{~b}$ and $\mathrm{d}$ indicated that the TEAC and superoxide anion radical scavenging capabilities of peptides 2 and 4, which were digested by pepsin, trypsin, or chymotrypsin, alone or continuously, remained at the same levels compared with those before digestion $(P>0.05)$. These results indicate that the active structures of antioxidant peptides 2 and 4 were not fully disrupted by intestinal proteases. Therefore, peptides 2 and 4 exhibited improved stability during the in vitro digestion process. The antioxidant activities of peptides 1 (Fig. 7a), 3 (Fig. 7c), and 5 (Fig. 7e) demonstrated insignificant changes $(P>0.05)$ when pepsin acted alone. This phenomenon might be due to the broad specificity of pepsin as an aspartic protease. Pepsin exhibits preferential cleavage of peptides with aromatic or dicarboxylic L-amino acid residues, that is, pepsin preferentially cleaves the C-terminal end of Phe [37]. Pepsin also breaks the peptides into small fragments, thus exposing a large number of internal groups, including some hydrophobic groups, to the environment. These results are consistent with those of $\mathrm{Zhu}$ et al. [36].

A previous study showed that the capability of peptides to resist enzymatic degradation partially depends on their amino acid composition [37]. chymotrypsin has relatively broad specificity and cleaves the $\mathrm{C}$-terminal end of hydrophobic residues, especially Phe, Tyr, Trp, and Leu [37]. Peptides 1 (Fig. 7a) and 3 (Fig. 7c) contain Phe, and peptide 5 (Fig. 7e) contains Trp and Phe, which are hydrophobic amino acids. These amino acids were individually or continuously degraded by chymotrypsin, resulting in a significant reduction in the antioxidant activity of peptides 1,3 , and $5(P<0.05)$. The same trend was also reported by Zhu [38].

The antioxidant activity of peptide 3 significantly declined $(P<0.05)$ when trypsin acted alone on peptides 1 (Fig. 7a), 3 (Fig. 7c), and 5 (Fig. 7e). Previous studies found that the degradation of basic and aromatic amino acids may decrease the antioxidant activities of peptides [37]. Trypsin is a highly specific endopeptidase that cleaves at the C-terminal end of Arg (basic amino acid) and Lys (aromatic amino acid) residues [39]. The composition of peptide 3 is Arg-Asn-Phe (Fig. 7c) and degraded by trypsin. Thus, the amino acid composition enables the peptide to resist enzymatic degradation. This conclusion is consistent with the results of previous research [39]. Therefore, peptides 2 and 4 exhibited good digestive stability in vitro and simulated gastrointestinal digestion.

\section{Conclusions}

In this study, the five new antioxidant peptides, respectively Cys-Gly-Phe-Pro-Gly-His-Cys, Gln-Ala-Cys, ArgAsn-Phe, Ser-Ser-Cys, and Trp-Phe, were purified from PWBP hydrolysates and evaluated for their antioxidant capacity and antioxidant stability. The five new peptides all exhibited antioxidant activity, among them Gln-AlaCys and Ser-Ser-Cys showing stronger antioxidant capacity. Furthermore, when the temperature was lower than $80{ }^{\circ} \mathrm{C}$, both Gln-Ala-Cys and Ser-Ser-Cys showed better temperature stability than other three peptides. Compared with other three peptides, Gln-Ala-Cys and SerSer-Cys also showed stronger digestive stability in vitro system by simulating gastrointestinal digestion. The current results provide useful information for PWBP hydrolysates and peptides and new ideas for the production of natural antioxidants instead of synthetic antioxidants. Moreover, these results enable the development and use of purple wheat bran.

\section{Abbreviations}

PWBP: Purple wheat bran protein; TEAC: Trolox equivalent antioxidant capacity; HPLC: High performance liquid chromatography; BHA: Butylated hydroxy anisole; BHT: Butylated hydroxytoluene; TBHQ: Tert-butylhydroquinone; ROS: Reactive oxygen species; DH: Degree of hydrolysis.

\section{Acknowledgments}

Not applicable.

\section{Authors' contributions}

YZ and QZ designed the work, collected and analyzed the data, and drafted the manuscript. YZ, QZ and QL revised manuscript draft. All authors read and approved the final manuscript.

\section{Funding}

This work was supported by the Open Project of National Engineering Laboratory of Wheat \& Corn Further Processing (NL2017003) and the Natural Science Project of Science and Technology Department of Henan Province (192102110110) for financial support. 


\section{Availability of data and materials}

The datasets and samples are available from the authors.

\section{Ethics approval and consent to participate}

This study was approved by National Engineering Laboratory of Wheat \& Corn Further Processing of Henan University of Technology University. All individual participants were voluntary and their all information is confidential. The study protocol was performed in accordance with relevant laws and institutional guidelines.

\section{Consent for publication}

Not applicable.

\section{Competing interests}

The authors declared no conflicts of interest.

\section{Author details}

${ }^{1}$ National Engineering Laboratory of Wheat \& Corn Further Processing, Henan University of Technology, Zhengzhou 450001 , China. ${ }^{2}$ College of Food Science and Technology, Henan University of Technology, Zhengzhou 450001, China.

\section{Received: 12 March 2020 Accepted: 2 September 2020}

Published online: 03 October 2020

\section{References}

1. Mattje LGB, Tormen L, Bombardelli MCM et al (2019) Ginger essential oil and supercritical extract as natural antioxidants in tilapia fish burger. J Food Process Preserv. https://doi.org/10.1111/jfpp.13942

2. Nascimento JA, Magnani M, Sousa JMB et al (2016) Assessment of the Antioxidant Effects of Moringa oleifera Lam. Extracts in Fish Oil during Storage. J Food Process Preserv 40:29-36. https://doi.org/10.1111/ jfpp. 12580

3. $\mathrm{Ng} \mathrm{KL}$, Tan GH, Khor SM (2017) Graphite nanocomposites sensor for multiplex detection of antioxidants in food. Food Chem 237:912-920. https:// doi.org/10.1016/j.foodchem.2017.06.029

4. Alinezhad H, Azimi R, Zare M et al (2013) Antioxidant and antihemolytic activities of ethanolic extract of flowers, leaves, and stems of hyssopus officinalis L. Var. angustifolius. Int J Food Prop 16:1169-1178. https://doi. org/10.1080/10942912.2011.578319

5. Li Z, jun, Yang F jian, Yang L, Zu Y gang, (2018) Comparison of the antioxidant effects of carnosic acid and synthetic antioxidants on tara seed oil. Chem Cent J 12:37. https://doi.org/10.1186/s13065-018-0387-4

6. Nissen LR, Månsson L, Bertelsen G et al (2000) Protection of dehydrated chicken meat by natural antioxidants as evaluated by electron spin resonance spectrometry. Journal of Agricultural and Food Chemistry 48:5548-5556. https://doi.org/10.1021/jf0003552

7. Jin DX, Liu XL, Zheng XQ, et al. (2016) Preparation of antioxidative corn protein hydrolysates, purification and evaluation of three novel corn antioxidant peptides. Food Chem 204:427-436. https://doi.org/10.1016/j. foodchem.2016.02.119

8. Devi KP, Rajavel T, Nabavi SF et al (2015) Hesperidin: A promising anticancer agent from nature. Ind Crops Prod 76:582-589. https://doi. org/10.1016/j.indcrop.2015.07.051

9. Sonklin C, Laohakunjit N, Kerdchoechuen O (2018) Assessment of antioxidant properties of membrane ultrafiltration peptides from mungbean meal protein hydrolysates. PeerJ 2018:e5337. https://doi.org/10.7717/ peerj.5337

10. Sarmadi BH, Ismail A (2010) Antioxidative peptides from food proteins: A review. Peptides 31:1949-1956. https://doi.org/10.1016/j.pepti des.2010.06.020

11. Xu F, Zhang J, Wang Z, et al (2018) Absorption and Metabolism of Peptide WDHHAPQLR Derived from Rapeseed Protein and Inhibition of HUVEC Apoptosis under Oxidative Stress. Journal of Agricultural and Food Chemistry 66:5178-5189. https://doi.org/10.1021/acs.jafc.8b01620

12. Carlos MGA, Walter M, Jonh JMA (2017) Antioxidant potential use of bioactive peptides derived from mung bean hydrolysates (Vigna Radiata). Afr J Food Sci 11:67-73. https://doi.org/10.5897/ajfs2016.1511

13. López-Perea P, Guzmán-Ortiz FA, Román-Gutiérrez AD et al (2019) Bioactive compounds and antioxidant activity of wheat bran and barley husk in the extracts with different polarity. Int J Food Prop 22:646-658. https:// doi.org/10.1080/10942912.2019.1600543

14. Thamnarathip P, Jangchud K, Nitisinprasert S, Vardhanabhuti B (2016) Identification of peptide molecular weight from rice bran protein hydrolysate with high antioxidant activity. J Cereal Sci 69:329-335. https://doi. org/10.1016/j.jcs.2016.04.011

15. Elias RJ, Kellerby SS, Decker EA (2008) Antioxidant activity of proteins and peptides. Crit Rev Food Sci Nutr 48:430-441. https://doi. org/10.1080/10408390701425615

16. Kou X, Gao J, Zhang Z et al (2013) Purification and identification of antioxidant peptides from chickpea (Cicer arietinum L.) albumin hydrolysates. LWT - Food Science and Technology 50:591-598. https://doi. org/10.1016/j.lwt.2012.08.002

17. Li W, Pickard MD, Beta T (2007) Effect of thermal processing on antioxidant properties of purple wheat bran. Food Chem 104:1080-1086. https ://doi.org/10.1016/j.foodchem.2007.01.024

18. Adlernissen J (1986) Enzymic hydrolysis of food proteins. Can Med Assoc J 172:1783-1785. https://doi.org/10.1503/cmaj.1041203

19. Randall RJLOHRNJFAL (1951) Protein measurement with the Folin phenol reagent. J Biol Chem 193:265-275. https://doi.org/10.1016/0922338X(96)89160-4

20. Xia Y, Bamdad F, Gänzle M, Chen L (2012) Fractionation and characterization of antioxidant peptides derived from barley glutelin by enzymatic hydrolysis. Food Chem 134:1509-1518. https://doi.org/10.1016/j.foodc hem.2012.03.063

21. Costa CSB, Chaves FC, Rombaldi CV, Souza CR (2018) Bioactive compounds and antioxidant activity of three biotypes of the sea asparagus Sarcocornia ambigua (Michx.) M.A.Alonso \& M.B.Crespo: a halophytic crop for cultivation with shrimp farm effluent. South African Journal of Botany 117:95-100. https://doi.org/10.1016/j.sajb.2018.05.011

22. Xing L, Liu R, Gao X et al (2018) The proteomics homology of antioxidant peptides extracted from dry-cured Xuanwei and Jinhua ham. Food Chem 266:420-426. https://doi.org/10.1016/j.foodchem.2018.06.034

23. Jang HL, Liceaga AM, Yoon KY (2016) Purification, characterisation and stability of an antioxidant peptide derived from sandfish (Arctoscopus japonicus) protein hydrolysates. Journal of Functional Foods 20:433-442. https://doi.org/10.1016/j.jff.2015.11.020

24. Valencia P, Pinto M, Almonacid S (2014) Identification of the key mechanisms involved in the hydrolysis of fish protein by Alcalase. Process Biochem 49:258-264. https://doi.org/10.1016/j.procbio.2013.11.012

25. Ovissipour M, Abedian A, Motamedzadegan A et al (2009) The effect of enzymatic hydrolysis time and temperature on the properties of protein hydrolysates from Persian sturgeon (Acipenser persicus) viscera. Food Chem 115:238-242. https://doi.org/10.1016/j.foodchem.2008.12.013

26. Rydberg HA, Kunze A, Carlsson N et al (2014) Peptide-membrane interactions of arginine-tryptophan peptides probed using quartz crystal microbalance with dissipation monitoring. Eur Biophys J 43:241-253. https:// doi.org/10.1007/s00249-014-0958-9

27. Kim SK, Kim YT, Byun HG et al (2001) Isolation and characterization of antioxidative peptides from gelatin hydrolysate of Alaska pollack skin. J Agric Food Chem 49:1984-1989. https://doi.org/10.1021/jf000494j

28. Qian ZJ, Jung WK, Kim SK (2008) Free radical scavenging activity of a novel antioxidative peptide purified from hydrolysate of bullfrog skin, Rana catesbeiana Shaw. Bioresour Technol 99:1690-1698. https://doi. org/10.1016/j.biortech.2007.04.005

29. Bamdad F, Chen L (2013) Antioxidant capacities of fractionated barley hordein hydrolysates in relation to peptide structures. Mol Nutr Food Res 57:493-503. https://doi.org/10.1002/mnfr.201200252

30. Saito K, Jin DH, Ogawa T et al (2003) Antioxidative properties of tripeptide libraries prepared by the combinatorial chemistry. J Agric Food Chem 51:3668-3674. https://doi.org/10.1021/jf021191n

31. Mendis E, Rajapakse N, Byun HG, Kim SK (2005) Investigation of jumbo squid (Dosidicus gigas) skin gelatin peptides for their in vitro antioxidant effects. Life Sci 77:2166-2178. https://doi.org/10.1016/j.lfs.2005.03.016

32. Harman LS, Mottley C, Mason RP (1984) Free radical metabolites of L-cysteine oxidation. J Biol Chem 259:234-241. https://doi. org/10.1007/978-1-349-86029-6_33

33. Valko M, Leibfritz D, Moncol J (2007) Free radicals and antioxidants in human disease. Int J Bioxhem Cell Biol. https://doi.org/10.1007/978-3319-67625-8 12 
34. Jin DX, Liu XL, Zheng XQ et al. (2016) Preparation of antioxidative corn protein hydrolysates, purification and evaluation of three novel corn antioxidant peptides. Food Chem 204:427-436. https://doi.org/10.1016/j. foodchem.2016.02.119

35. Grütter MG, Hawkes RB, Matthews BW (1979) Molecular basis of thermostability in the lysozyme from bacteriophage T4. Nature 277:667-669. https://doi.org/10.1038/277667a0

36. Zhu, Zhang WG, Kang ZL et al (2014) Stability of an antioxidant peptide extracted from Jinhua ham. Meat Sci 96:783-789. https://doi. org/10.1016/j.meatsci.2013.09.004

37. Ao Li, Bo J (2013) Stability and antioxidative activities of casein peptide fractions during simulated gastrointestinal digestion in vitro: Charge properties of peptides affect digestive stability. Food Res Int 52:334-341. https://doi.org/10.1016/j.foodres.2013.03.036
38. Zhu L, Jie C, Tang $X$, Xiong YL (2008) Reducing, radical scavenging, and chelation properties of in vitro digests of alcalase-treated zein hydrolysate. J Agric Food Chem 56:2714-2721. https://doi.org/10.1021/jf703 697e

39 Olsen JV, Ong SE, Mann M (2004) Trypsin cleaves exclusively C-terminal to arginine and lysine residues. Mol Cell Proteom 3:608-614. https://doi. org/10.1074/mcp.T400003-MCP200

\section{Publisher's Note}

Springer Nature remains neutral with regard to jurisdictional claims in published maps and institutional affiliations.
Ready to submit your research? Choose BMC and benefit from:

- fast, convenient online submission

- thorough peer review by experienced researchers in your field

- rapid publication on acceptance

- support for research data, including large and complex data types

- gold Open Access which fosters wider collaboration and increased citations

- maximum visibility for your research: over $100 \mathrm{M}$ website views per year

At BMC, research is always in progress.

Learn more biomedcentral.com/submissions 